To understand the process of defending human rights entirely first of all it's noteworthy to study its origin and development. The issue of human rights has its prehistory and is connected with the development of society, state and humanity.

"In the current stage of historical development of humanity the defense of human rights is the real indicator of any leading society. And the process of giving them certain description is the property of the state which is following the radical civilization"( Falk 1981).

Historically the first viewpoints of dignity and the autonomous position of an individual towards historical government belong to philosophers, historicians and lawyers of Ancient Greece and Rome. It's worth mentioning that in that period nobody has an idea about "human rights" in Ancient Greece and Rome.

In the Middle Ages freedom was restricted as the feudal society was a society of a universal dependence. There was dominating willfulness and power. But in that period in England they were trying to restrict the rights of monarchy and establish some rules for the monarch to follow them. The antagonism of monarchs, barons and knights was over in 1215 by the adoption of "Magna Charta".

Magna Charta fixed the victory carried by the nobility of England towards monarch. Studying the articles of Magna Charta we can conclude that its main content is the following:

The king must preserve feudal routine with his vassals.

Taxes are obliged to levying only in case of general council's decision.

Any arrest should be based on the testimony of trustful witnesses.

People can be arrested, expelled, disgraced only by legal judgment.

The importance of the mentioned document is that there is fixed the inviolability right of a free person. That is, a person can be arrested and imprisoned only on the bases of legal sentence of a court. "Magna Charta" is the statute which gave a rise to the development of the modern institution of a person's testimony.

The other important Act in this field is "The editor on Rights" 1628, which refers to the development period of bourgeois orders in England. The main statements of that Act are:

Constitutional monarchy should define taxes only by councils decision.

Arrests should take place only in a legal order.

Extreme courts should be abolished.

The next important step for the Human Rights was "the Habeas Corpus" Act, 1679 which is the constituent part of England's unwritten constitution. It can be called like "Act on warrants of Human Rights". It's the only Act in human history in which not only the Human Rights are declared but also the warrants of their provision are fixed. According to the Act:

A written Order is needed for arresting a person otherwise the imprisoned should be set free or represented to the nearest court which has to solve the problem. In case of the absence of enough bases for arrest the court is competent to set free the imprisoned.

The arrested has the right to demand to represent him to the nearest court for the solution of his imprisonment. The obstructive functionary of implementing this request is subject to punishment (fine).

According to Habeas Corpus the relatives of the arrested have the right to apply to the High

Court. The law wasn't applied only in regard of the deceivers of fatherland.

The above mentioned Act played great role in the development of modern international criteria of human rights.

The further development of freedom ideals and human rights reflected in the famous historical documents occurred in the USA where in 1776 the declaration of Virginia rights was adopted. The latter declared that all people are free and independent and have some natural rights. And at last "The Declaration of human rights" in France (1789) is worth mentioning, which is today the inseparable part of the current constitution (Human Rights 1997). The Declaration castigates the ancient feudal orders and declares "Natural, inseparable and sacred human rights".

Let's mention the most important of them:

People are free and have equal rights. The state is called to protect the freedom, property and security of citizens. People have the right to confront the exploitation.

The supreme power of a state belongs to the people.

Freedom is the chance of the activities which don't contradict other's interests."Anything which doesn't contradict the law is permissible." 
The law should manifest the will of each member of a society and that's why everybody can take part directly or indirectly in the law development activity.

The $7^{\text {th }}$ and $8^{\text {th }}$ articles of the Declaration define the most vital strategies of the criminal law:

"there is no crime which is not defined by law" and "there is no punishment which is not defined by law".

$\square \quad$ The $9^{\text {th }}$ article of the Declaration fixes the strategy of innocence hypothesis according to which "each arrested is considered to be innocent unless the opposite is proved".

The $17^{\text {th }}$ article of the Declaration fixes "the immunity and sacred right of property". Declaration also discusses the freedom of speech, press and meetings.

The above mentioned English, American and French domestic Acts played great role in the development of Human rights and predicted the contents of the international criteria of human rights.

All human rights and freedom enter the system of human rights which is the interconnected entity of the first, second and the third generation's rights.

The system of Human Rights together with the mechanisms of supporting warrants is of universal importance for humanity as it acts as a means for protecting and overcoming from dangerous universal threats.

In each historical period humanity has struggled for the declaration and guaranty of certain law groups. So, the history of declaration of human rights has passed through certain stages. The groups of gained laws in each period are accepted to call "generations" of human rights and freedom. Nowadays three Law generations are known. They reflect the historical succession of human rights' perception and the time succession of their inclusion in international legal documents. According to their implementation field each generation's Laws are subdivided into different groups.

For the first time they were fixed entirely in "the French Declaration of Human and Citizen Rights" and in "the American Bill on Law". Civil and political laws are also among them. These laws determine the rights of person's life and dignity, rights of freedom and immunity as well as of private life, inviolability of the home, the freedom of move and choice of living place, freedom of conscience, nation, and communication and the choice of a language. Political rights and liberties are:

Electoral law

Freedom of speech, the constituent parts of which are: freedom of thought, freedom of media, freedom of meetings and demonstrations.

Unification Law

Address Law

The free development, independence and immunity of a person preserve him or her from the undesirable freedom braking interference and restriction.

Civil Laws are called to guarantee the self-government and freedom of a person, to protect him from the tyranny of the state.

The second generation was developed during the struggle for improvement of economical state and for the raise of cultural state. The Laws fixed by the second generation are only a few decades old what doesn't reduce their meaning. They started to develop after the First World War and are somehow the result of Soviet Russia and then efforts of USSR.

The Laws of second generation were known as international in the Universal Declaration on Human Rights, 1948. Among them are economic, social and cultural Laws. The economic Laws are:

Job law

property law

Strike law

Commercial activity law.

Social Laws are:

Social safety law

Satisfactory living standard law 


\section{Maternity law}

Physical and mental health law

Innocence protection law.

The Laws of second generation are the strengthening conditions of life which let everybody develop freely their human nature and give bases for the exclusion of violence. The implementation of the second generation Laws is much more difficult than that of the first one as for that we need highly developed economy and rich resources. According to the $22^{\text {nd }}$ article of the universal declaration on Human Rights each person as a member of a society has the right of social support, the right of keeping it's social and cultural dignity, implementing needed laws for it's development with the help of international corporation and under the structure and resources of each country.

According to "the International agreement on economic, social and cultural Laws" human ideal who is free from any kind of fear and demand can implement the laws in case of such conditions which will give everybody the opportunity to enjoy economic, social, cultural as well as civil and political rights (Human Rights and Court Procedure 1996).

The western countries interpret those documents in the sense that the laws defined by the "International agreement on civil and political laws" are law obligations whereas the ones mentioned in the "International agreement on economic, social and cultural laws" are just kinds of wishes which are not obligatory. So this continued up to 1986 when the position of western countries was steadily changed in favour of some circumstances. First of all leading experts of different countries came to the conclusion that all human rights are inseparable and

interconnected. Second, the general Assembly of the UNO confirmed the resolution about the inseparability and correlation of economic, social, cultural, civil and political laws on $4^{\text {th }}$ December 1986. The solution to this issue was given in Vienna 1993, during the international conference on human rights.

After 1986 the general Assembly of UNO stressed that no law should be opposed to other laws or be interpreted in prejudice of them.

After the Second World War the second generations of human rights started to develop.These laws are sometimes called amity laws. These laws are combined and worth discussing. The peculiarity of these laws is that they are collective and can be used by the community.

The second generation laws are:

Development law

Clean environment law

Peace law

Heredity law

Minorities law

Using high qualified food products law.

Nowadays international community pays great attention to the Development law. It is universal and is inseparable for all nations making up the organic part of the main human rights and freedom. This law was entirely fixed by the "Declaration on Development Law" adopted by the main Assembly of UNO in1986. 